Pelkmans, Mathijs. Forthcoming, 2021. In Comparative Studies in Society and History 63 (1): tbc.

Accepted Version

\title{
Frontier Dynamics: Reflections on Evangelical and Tablighi Missions
}

\section{in Central Asia}

Mathijs Pelkmans

Abstract. Missionaries have flocked to the Kyrgyz Republic ever since the collapse of the Soviet Union. Evangelical-Pentecostal and Tablighi missions have been particularly active on what they conceive of as a fertile post-atheist frontier. But as these missions project their message of truth onto the frontier, the dangers of the frontier may overwhelm them. Based on long-term ethnographic fieldwork amongst foreign and local Tablighis and evangelical-Pentecostals, this article formulates an analytic of the frontier that highlights the affective and relational characteristics of missionary activities and their effects. This analytic explains why and how missionaries are attracted to the frontier, as well as some of the successes and failures of their expansionist efforts. In doing so the article reveals the potency of instability, a feature that is particularly evident in missionary work, but resonates with other frontier situations.

Key words. Central Asia, frontiers, religious missions, missionaries, topology, Islam, evangelical Christianity

\section{Introduction}

By way of introduction let me revisit an encounter from the early stages of my fieldwork on missionary activities. ${ }^{1}$ Back then, in 2003, I was primarily interested in the conversion of Kyrgyz people to evangelical Christianity in the post-Soviet period. The topic of Christian missionary activity tended to trigger negative comments locally, and with that in mind I 
entered a mosque in the small city of Karakol in north-eastern Kyrgyzstan, where I approached a group of men who were seated on the floor. Not knowing that they were involved with the Islamic missionary movement Tablighi Jamaat, I was surprised that my probing into their views of Christian missionaries and of Muslims converting to Christianity triggered a calm, reflective commentary. They told me, and I paraphrase them here:

Those converted Kyrgyz had never been real Muslims; they had been atheists, Islam had merely been culture to them. After the collapse of the Soviet Union, Christians had been more active in carrying out mission work than Muslims; but this is changing now that more Muslims [such as themselves] are getting involved in calling people closer to Islam.

The response surprised me because it suggested a different attitude to religion than what I had become accustomed to. Most Kyrgyzstani citizens considered Islam to be as inalienable from Kyrgyz culture as Christianity from Russian culture. ${ }^{2}$ This logic had allowed for a truce between what in Central Asia were labelled the 'traditional religions': Orthodox Christianity and mainstream Sunni Islam. Its dignitaries proudly pointed out that in Central Asia for over a century their religions had co-existed in peace, each taking care of their own. ${ }^{3}$ The Tablighis rejected this set of ideas. They dismissed the popular equation of religion and ethnic culture; instead they embraced the idea that they were operating in an open religious field (in which they could advance their 'exclusivist' notions of faithful belonging). Significantly, their ideas about the separation of religion and culture as well as the emphasis on choice in individual religious trajectories were shared by evangelical Christians who 
emphasized ideas of freedom and civil society, and who depicted post-Soviet Kyrgyzstan as a religious market, a mission field where 'Cults and other teachings have flooded into the country as the harvest field is ripe'. ${ }^{4}$

As the conversation proceeded it also became evident that the Tablighis engaged with me on distinctly unequal terms. They did not consider me an equal conversation partner, but rather a potentially responsive listener at the receiving end of a one-way communication channel. ${ }^{5}$ They positioned themselves as the bearers of an unshakable truth, and expressed certainty through their calm and pensive manner of speaking. Sharing this truth with others was what had brought them to the mosque. They were 'travellers' participating in a dawat or proselytizing tour, during which they invited others to the right path, meanwhile strengthening their own connection with God. Although their calm and self-contained comportment struck me as different from the often more expressive style of my Pentecostal Christian acquaintances, the underlying logic was similar: it was about establishing an asymmetric relationship to draw listeners into a religious discourse and direct them toward the truth.

The Tablighi Jamaat and the Church of Jesus Christ - which is the evangelicalPentecostal church that I have followed most closely ${ }^{6}$ - both successfully established themselves in Kyrgyzstan in the 1990s, and experienced rapid expansion in the decades thereafter. The Tablighi Jamaat first came to Kyrgyzstan in 1992, when Tablighis from Pakistan visited the country on a proselytizing tour and introduced a small group of Kyrgyz to its teachings (Toktogulova 2014: 7). Initially the movement made little headway, but after around the year 2000 it rapidly expanded, reaching 10,000 participants by 2007 , most of whom were ethnic Kyrgyz (Rotar 2007). Since then its growth has slowed down, with 
alternating periods of contraction and expansion (Ismailbekova and Nasritdinov 2012: 186). The trajectory of the Church of Jesus Christ has been rather similar. It was established in 1991 by a small group of Russians who had become dissatisfied with the legalistic approach and inward-looking atmosphere in the Soviet-era underground Pentecostal church to which they had belonged until then. The Church grew quickly in subsequent years, reaching 500 in 1994 and 10,000 tithe-paying members in 2003. The number of church members - of whom approximately 40 percent was Russian and 45 percent Kyrgyz - stabilized thereafter. ${ }^{7}$

The above outlines sound straightforward enough: representatives of religious movements enter a promising 'mission field'; they foster a religious sensibility that places the individual at centre stage; and they see themselves as actors operating in a pluralistic environment or religious market. In fact, these elements resonate with writings about trends in Islam and Christianity worldwide, and according to Berger are central to the success of what he terms 'passionate religious movements' (1999: 2). The emphasis on the individual is not only evident in evangelical notions of 'sincerity' and 'salvation' (Bielo 2011; Coleman and Hackett 2015: 17); framed as 'interiority' and the 'moral self' they are at the heart of new Islamic piety movements (Liberatore 2017: 213; Mahmood 2005; Roy 2006). Moreover, their person-centred approach is congruent with the rise of new forms of pluralism in the age of globalization. ${ }^{8}$ Whether or not one agrees with the argument of several sociologists that 'religious pluralism leads to the religious vitality of many lively religious groups' (as Bender (2015: 66) critically summarizes their position), there are clear affinities between the person-centric and interiority-focused teachings of 'passionate' and 'neofundamentalist' religious movements and the ideology of the free market and the reality of state withdrawal (see also Roy 2006). 
In fact, these trends can be easily mapped onto changes in the religious landscape in Kyrgyzstan. The collapse of the militantly secular Soviet Union and the adoption of liberal laws allowed for religion to return to the public sphere, and for a range of religious movements to start or expand their activities. Moreover, the dislocations and disorientations produced by the collapse of the Soviet welfare state can safely be said to have increased the appeal of moral communities that offered clear answers to personal predicaments. On the surface, then, the religious dynamism observed in post-Soviet Kyrgyzstan affirms the prediction of market theorists of religion that religious liberalization and pluralization boosts religious activity (e.g. Stark and Finke 2000; for Kyrgyzstan, Radford 2015). Moreover, the notions of pluralization, individuation, and marketization resonated with how Tablighis and Evangelical presented their own proselytising activities and defended their religious rights (see also Pelkmans 2009; 2014).

And yet, this conceptualization tends to leave important aspects of missionizing unseen, as hinted at by the short vignettes: the missionaries' sense of superiority and the associated asymmetries in communication; the expansionist focus in trying to bring the truth to the 'lost' and the 'unreached' (that is, to the perceived victims of Soviet atheist rule, and to those who never had the opportunity to hear the relevant religious truth); and the affective energies released by the missionaries' conviction. These aspects ought to be central ingredients of an approach that aims to understand the missionary drive and more broadly the dynamics of religious expansion and intensification. Hence, the 'amorphous' notions of market, pluralism, and personhood need to be augmented by a more relational conceptualization of the social field, one that reflects the spatial and temporal unevenness of such fields. The concept of the frontier holds particular promise, as it draws attention to 
the relational logics of connection and expansion as well as the affective dimensions of potential and the unknown. ${ }^{9}$

In order to integrate these dimensions, I develop in the next section a topological analytic of the frontier; one that is concerned with the consistency and elasticity of the social field (Mol and Law 1994: 643; Law 1999). Emphasizing the complexity of connection, I hold that an understanding of the fluctuating intensities of missionary activity on the religious frontier requires studying how connections are affectively, morally, and epistemically constituted; and moreover that this approach can shed light on other frontiers as well. Indeed, the drive of expansion, sense of superiority, and conviction of truth is not unique to religious missions, but resonates with political-economic asymmetric encounters, such as in projects of state encapsulation, extractive capitalist expansion, and (neo-)imperial 'civilising missions'. Ultimately, then, by scrutinizing two religious missions, this article aims to unveil some of the mechanisms, tensions, and connections that constitute what I refer to as 'frontier dynamics'.

\section{The Frontier as a Topological Object}

Topography and topology both concern the spatial (from the Greek topos), but otherwise have little in common. Topography refers to acts of mapping (categorizing, classifying, enumerating) attributes across a surface, whether these are mountains, rivers, or cities in a landscape, or people and institutions in a social field. Topology, by contrast, describes the spatio-temporal ordering of landscapes or social fields: it concerns the consistency of these fields and the behaviour of their properties in relation to each other. In an early piece on the matter, Mol and Law (1994) clarify this by differentiating between several interrelated 
topological modalities: 'regions' are about clustering and binding; 'networks' are about connectivity; and 'fluids' allow transformation without fracture (1994: 642-43). Their point is not so much to identify topological formats as to reflect on the complexity of spatiotemporal ordering. Crucially, this ordering impacts not only the elements that are contained, but the dynamics of the broader social field. Analogously, topological reflection on the frontier serves the goal of obtaining a better grasp of the social and ideational dynamics that drive religious missions.

In one of its shorthand definitions, 'frontier' refers to the edge of a formation. James Scott, for instance, talks about the frontier in upland Southeast Asia as a region removed from the centres of power; a zone of refuge and freedom that thereby fosters more egalitarian relationships (2009: 19). Frontier is also used as an alternative for 'boundary', especially to emphasize the zonal rather than linear characteristics of the meeting points between polities, countries, or empires. Thus, for Kopytoff (1987) the African frontier refers to the margins between polities - which he describes as zones of turmoil with the potential to develop into new societies (1987: 5-7). Directly and indirectly, these writings bear the mark not only of Leach's (1954) description of an escape social culture that was itself unstable, but also Owen Lattimore's remark that 'it is not surprising that the ambivalent loyalties of frontier people are always conspicuous and historically important' (1968: 374).

All of this strongly suggests that the identified creativity, egalitarianism, and ambivalence are not simply attributable to an 'open' or 'free' space (as in the idea of the market) but are also complex responses to asymmetric centre-periphery relations. That is, frontier activity is simultaneously located on the margins and entangled in networks that extend from the centre. Moreover, the centre-periphery relationship is always a contentious 
one, not least because "the definition of the frontier as "empty" is political and made from the intruders' perspective' (Kopytoff 1987: 25) and should thus not be accepted as fact. Indeed, emptiness and wildness do not have stable ontologies but are the unstable product of expansionist visions and fantasies. As Anna Tsing puts it, frontiers emerge as part of efforts to 'create wildness so that some - and not others - may reap its rewards' (2005: 27).

Another definition of the frontier can be gleaned from offhanded usage of the term, such as when academics speak of 'frontiers of knowledge', investors of 'resource frontiers' and missionaries of 'mission frontiers'. In their different ways, they are all evoking the idea of potential that is yet to be realized. This issue of realization resonates with recent attention in anthropology to how life projects are constituted through projections of the imagination and the will. Whether this takes the form of a Heidegger-inspired focus on 'potentiality' (e.g. Gammeltoft 2013) or a Deleuze-inspired reflection on 'becoming' (e.g. Biehl and Locke 2010), they share a future-oriented emphasis on subject formation, where the incomplete present is constantly refracted through its engagement with that which is yet to come. Frontiers in this sense are 'horizons of the imagination', offering a perspectival mechanism by which an unreachable 'beyond' animates - through anxiety, fear, desire, hope - 'the insistent reality of the here and now', as Crapanzano (2004: 14) puts it.

A useful way to merge these two understandings of the frontier is to revisit Frederick Jackson Turner's highly problematic yet insightful essay 'The Significance of the Frontier in American History' (1921). His ecologically deterministic Frontier Thesis holds that American society emerged as the product of the conditions of the frontier, in essence that the encounter with the wilderness and the abundance of open land pushed individuals to become mobile, self-reliant, innovative, and merit-focused, that is, adopting characteristics 
presumed to underpin American capitalism and democracy (Bassin 1993: 486). Even though the Frontier Thesis has repeatedly been debunked, ${ }^{10}$ its influence has continued unabated. As Limerick puts it, the Frontier Thesis has been 'exempted from the usual tests of verification, evidence, and accuracy' (1995: 700). There seem to be at least two reasons for this. First, Turner formulated, even if only at a rudimentary level, a topological definition of the frontier that has continued to trigger the analytic imagination. Second, his mythologized depiction of the frontier continues to hold appeal to those who cast themselves as pioneers of sorts. These two reasons each require elaboration.

Analytically, Turner touched on an essential point. For him, the frontier was not just that which lies at the margins, but rather a figuration with its own dynamic, spurred on by the possibilities provided by the receding horizon of the wilderness. He described 'the frontier [as] the outer edge of the wave' (1921: 3), and later in his essay suggested that there are multiple frontiers, 'series of waves', that 'rolled one after the other' (1921: 19). The image of the wave powerfully evokes the relational and affective dimensions that constitute the space-time of the frontier. The frontier is a figuration that - like a wave builds up, extends its reach, to then release its energy. Scott Lash's description of topological objects fits seamlessly: 'through their own energetics, they drive their own space and time' (2012: 262). Despite the many faults of Turner's environmentally deterministic model, his vision of the frontier as a forward-pushing figuration with its own dynamic resonates with how Anna Tsing conceptualizes the capitalist frontier: 'an edge of space and time: a zone of not yet - not yet mapped, "not yet" regulated" (2003: 5100). This also indicates that the frontier is temporally confined - a figuration that emerges in specific conditions but over time will give way to other arrangements. 
One of the many problematic aspects of Turner's Frontier Thesis is the idealization of the colonist and the frontier conditions. He cites the colonist's presumed 'love of the wilderness' (1921: 22) and describes how at 'the meeting point between savagery and civilization' (1921: 3) the colonist 'slowly transforms the wilderness' (1921: 4) to create a vibrant new society. The Frontier Thesis has rightly been debunked for its arrogance, for diminishing the human cost of colonization, and for its mythologized and essentialized depiction of the American nation. It is always crucial to remember that the frontier is experienced radically differently by the colonized and the dominated (Anzaldua 1987). But as a concept the frontier is useful not in spite of but because of its politically suspect connotations: it draws attention to how elites refract reality through their prisms of asserted superiority and (assumed) dominance. Indeed, the elitist bias of the Frontier Thesis is precisely why it resonates with that of settlers, colonists, and indeed missionaries, and therefore should be taken serious when analysing expansionist projects. After all, the ideal of expansion and the conveyed sense of superiority were evident in the disposition of Tablighis and evangelical-Pentecostals, and in their emphasis on the importance of invitation and evangelization.

So, how does Central Asia, and Kyrgyzstan specifically, fit in these discussions of the frontier? Although this article focuses on religious missions in the post-Soviet period, it is not irrelevant that Central Asia has historically often been placed on the margins of larger civilizational formations. As Andre Gunder Frank put it, Central Asia appears as a sort of 'black hole in the middle of the world', seen by historians and representatives of the surrounding Chinese, Persian, and Russian civilizations 'as a dark tabula rasa on which itinerant monks, mullahs, and artists from these allegedly civilized areas left their marks' (1992: 50). Frank's aim is to show that Central Asia's interconnecting position actually made 
it central to world history, but here it is the image of Central Asia as a peripheral frontier that is relevant. For Tsarist Russia, Central Asia was its internal Orient that first needed to be 'pacified' and then 'civilized', all the while serving as the destination point for waves of European settlers (Brower 2003; Khodarkovsky 2002). Jumping forward, although the Bolsheviks presented themselves as a liberating force, they looked at Central Asia through a Eurocentric prism, treating it as a problematic backwater and a target for its high modernist civilising mission, as a result of which 'inefficient' pastoral ways of life would be replaced by sedentary and modern lifestyles. Its normative standard had distinct Russian overtones, such that Islamic practices appeared not only as 'backward' but also 'alien' (Keller 2001: xv).

The Soviet regime ultimately failed to eradicate Islam in Central Asia, but its antireligious policies and efforts to create a secular society curtailed and destabilized the position of Islam (e.g. Khalid 2007; Louw 2007: 21; Hann and Pelkmans 2009). Not surprising, therefore, that in the post-Soviet aftermath Central Asia once again emerged as a canvas onto which a range of 'civilising missions' projected their assumed superiority. Kyrgyzstan was particularly attractive for such projections because its fast and far-reaching deregulation of the public sphere offered more scope to foreign-driven activity than existed in neighbouring countries. ${ }^{11}$ It became, as it were, a 'laboratory' for testing out ideologies a mission field for democracy champions to propagate the values of liberalism, for development specialists to demonstrate the efficiencies of the free market, and for religious missionaries to proclaim the truth and promise salvation (Pelkmans 2017: 9).

To appreciate the features of this new mission field, it is essential to see it as both project and margin. Within this space, religious movements, the people amongst whom missionaries work and the techniques they deploy should not be viewed as discrete and 
separable entities, but as complexly entangled components. Here it is useful to return to Law and Mol's (1994) differentiation of social topologies into those of region, network, and fluid. As a 'region' Kyrgyzstan was perceived as the edge of a formation, a loose clustering of 'former communists' or 'bad Muslims'. Here, missionaries worked to insert their immutable truths, thereby extending 'networks' that linked them to their home congregation or religious centre. ${ }^{12}$ But if the 'region' is thus shot through by a 'network' logic, these logics are both modified by the 'fluid' characteristics of praxis (cf. Mol and Law 1994: 658). When missionary activities are adjusted to new contexts, this affects not only the consistency of the 'mission field' but potentially also the messages and techniques of missionizing.

The point is that in missionizing these different relational logics combine to produce a distinct frontier figuration. Picking up on Turner's (1921) metaphor, this figuration behaves like a wave that builds momentum and pushes forward, but is always at risk of receding or collapsing. Here we see an additional advantage of the frontier concept, namely that it draws attention to uncertainty and instability. Or to use the words of an influential evangelical missiologist, the frontier represents that 'beyond which we must go, yet beyond which we may not be able to see clearly' (Winter 2005:155). The implied difficulty is amplified by the fact that in contrast to some other pioneers, the success of missionary work is dependent on establishing meaningful relations with the 'other'. Within this space of un-clarity and uncertainty mission work is unstable, for at least two reasons. First, as missionaries move deeper into the frontier, they risk being increasingly ignored, potentially eroding the conviction with which they set out. Second, the frontier may overwhelm the missionary who then, as it were, falls over to the other side. As we will see, missionary movements have devised mechanisms to counteract these risks. But because these 
mechanisms are imperfect, the possibility remains that missionary advances result in pyrrhic victories, in the loss of conviction, and even the collapse of the missionary effort as a whole.

\section{The Drive Forward}

Let me start this section by quoting another classical definition of the frontier, this one by political scientist Ladis Kristof, who reflects on the term's usage in historical discussions of state formation and expansion:

$[T]$ he frontier was not the end ('tail') but rather the beginning ('forehead') . . it was the spearhead of light and knowledge expanding into the realm of darkness and the unknown ... pioneer settlements of a forward moving culture bent on occupying the whole area (Kristof 1959: 270).

The topological qualities of the frontier are unmistakably present in this definition. The frontier is seen as the extension of the centre, stretching and reaching to connect with, and overpower, that which is found in its way. As such it powerfully conveys the perspective of the settler, the pioneer, or the missionary, as they look out over what to them appears as barren land, an expanse into which they can venture, and which they set out to appropriate by transforming it, a process through which they are themselves rejuvenated. This vision closely corresponds with the definition provided by the already mentioned missiologist who writes that mission frontiers are 'related to the glorification of God in all the nations (peoples) of the world, to "open their eyes, to turn them from darkness to the light and 
from the power of Satan to God" (Acts 26: 18)' (Winter 2005: 155). In evangelical discourse, the frontier refers to the effort of spreading the Good News of the Gospel to those who haven't heard yet; it is about 'reaching the unreached', with special attention to the Muslim world. ${ }^{13}$ So, let me turn to these evangelical visions first.

Evangelical visions of missionary work

Among North American and European evangelicals, the opening up of post-Soviet Central Asia as a potential mission field triggered significant enthusiasm. It brought together two evangelical dreams: first to carry the Gospel to the atheists of the crumbling Soviet Union, and second to establish a bridgehead to the always resistant Muslim world. Numerous articles appeared in evangelical outlets such as the International Journal of Frontier Missions; ${ }^{14}$ congregations in the U.S. adopted their own Central Asian 'unreached people group' to turn them into recipients of collective prayer and sometimes of a church-funded missionary family; and a range of mission organizations started educational, humanitarian, publishing, and legal advice programs in the region (see van Gorder 2009). Within Central Asia, Kyrgyzstan received a disproportionally large share of missionary initiatives, not least because between 1991 and 2008 the country imposed few obstacles to religious activity.

The evangelical expansionist drive was encoded in the design of the evangelicalPentecostal 'Church of Jesus Christ', a church that received considerable international support but was led by Kyrgyzstani pastors (Russians as well as Kyrgyz). Here, missionizing was not an external or specialized activity, but an integral aspect of religious practice, as also reflected in the title of a book popular among church members: kazhdyi khristianin missioner (Every Christian is a Missionary). The book details how through prayer, by 
witnessing to neighbours and relatives, and by taking part in evangelization activities, socalled 'believers' carry out their religious duty and realize themselves as Christians. ${ }^{15}$ During church services, these ideas surfaced not only in sermons, but were practiced by congregants who were invited to the stage to share their personal stories of having witnessed God's grace - of how they overcame addictions or achieved success in life. ${ }^{16}$ Most congregants also convened weekly in smaller prayer groups to direct their spiritual energies to reach out to politicians, prisoners, or the inhabitants of a particular district. Promising church members were encouraged to establish their own congregation, thereby advancing missionary work to all corners of the Kyrgyz Republic.

The missionary drive and the pull of the frontier converged in the person of pastor Kadyrjan. Himself being of Kyrgyz Muslim background, Kadyrjan had come to faith in Kyrgyzstan's capital Bishkek in 1996. His enthusiasm and his talents were recognized by senior pastors in the Church of Jesus Christ, with the result that he rapidly made his way up the church ranks. Three years later he was, as he phrased it, 'called by God' to establish his own congregation; he and his family moved to Jalalabad, the capital of a province (oblast) with the same name and which in Kyrgyzstan has the reputation of being 'very Islamic'. Kadyrjan often talked about the obstacles that he and his family had overcome: they had experienced severe shortage of money; at times they even had been close to starvation; the local population had initially taken him and his wife for shamans; the premises they rented for church activities were declared unavailable time and again. Through elaborating on these and other difficulties Kadyrjan presented himself as a pioneer, a tool in the hands of God, enlisted in a mission to defeat the dark forces that surrounded his congregation. 
This self-righteous attitude, which was based on a perceived contrast between the 'spearhead of light' and the 'realm of darkness' (Kristof 1959), shone through strongly in many of my conversations with Kadyrjan. 'You should imagine what the city looked like when we first arrived', he told me. 'Garbage was not collected for weeks, the streets were littered. And it was pitch dark at night. No street lights. Back then you would sit at home listen to the dogs howling outside'. Kadyrjan emphasized that partly through the active prayer of his congregation, the city had started to prosper. If previously the bazaar had resembled a filthy swamp, its unhygienic market stalls were increasingly being replaced by proper 'European' shops. Moreover, he claimed, crime levels had fallen since God's work had started to enlighten the city. And not unimportantly, his congregation had flourished, counting 250 tithe-paying members in 2004, the majority of whom were ethnic Kyrgyz. With these successes under his belt, the new frontier for Kadyrjan consisted of the smaller settlements in the region. Of these the mining town of Kokjangak stood out. In his sermons he dwelled on the various evil spirits that still kept this town in their 'ice cold' grip. Conquering Kokjangak (in the sense of establishing a thriving congregation) would deliver a decisive blow to Satan, and thus not only save the converted but achieve an important victory for Jesus in the region.

Kadyrjan certainly was not the only missionary preoccupied with the ultimate frontier. In the evangelical expat community in Bishkek, there was always much interest in how congregations in the provinces were doing, especially in the 'Islamic' south, just like there was a lot of talk about how Kyrgyzstan would serve as a bridgehead for missionary work elsewhere. Several American missionaries were preparing for mission work among the Kyrgyz minority in China, who were deemed truly 'unreached', whereas others focused their attention on training Kyrgyz, Uyghur, and Uzbek church members for missionary work in 
settings seen as particularly hostile. Because of this, there was deep fascination with Shavkat, the pastor of a small Uzbek congregation. Uzbeks had proven to be more resistant to evangelization than Kyrgyz, but Shavkat and his family had stood fast in the face of communal ostracizing, attempted eviction, and even death threats. The case of Shavkat was seen as a litmus test, and hence it was no surprise that dozens of foreign missionaries and Kyrgyzstani Christians from other regions travelled to Shavkat's village to offer their visible support by attending a 'circumcision party' in honour of his son. ${ }^{17}$ Shavkat and his family were proper heroes for the evangelical community, frequently brought up in conversation, and actively supported.

These stories about opposition, heroic suffering, and anticipated victory had an invigorating effect - they were inspirational, thereby contributing to the cohesiveness of the group, and reinforcing the idea that congregants were God's chosen people. The productive tension, which is a key element of frontier dynamics, clearly shone through when Kadyrjan told me with an air of mischievous enthusiasm: 'We pray [for local officials] to stop hindering us. But that may not be God's way. Our faith thrives when it is being repressed'.

\section{Tablighi visions of dawat or invitation}

The Tablighi Jamaat originated in the 1920s in North India as a response to Hindu attempts to 'reconvert' nominal Muslims to Hinduism (Metcalf 2003: 137), and developed its focus 'on conversion of non-Muslims to Islam [...] in reaction to European Christian missions' (Masud 2000: xxvi). Hence, missionizing has been an integral part of the method of tabligh (literally, 'conveying the message'), a method aimed at fostering spiritual regeneration. Its model is built around the practice of dawat. It is worthwhile to briefly reflect on this term 
and its derivation from the Arabic $d a^{\prime} w a$, which literally translates as inviting or calling. In his book on the Tablighi Jamaat the prominent Islamic theologian Muhammad Masud points out that $d a^{\prime} w a$ means mission when used to refer to the practice of inviting others to the truth (2000: xxi). He elaborates that in the Qur'an the term ' $d a^{\prime}$ 'wa combines two acts simultaneously: invitation and claim. When someone invites another to God he also claims the truth of his mission'. This dovetails with how the term is used in Kyrgyzstan, where becoming a Tablighi is referred to as becoming a dawatchi-someone who goes on dawat. ${ }^{18}$ According to the method of Tabligh, dawatchis should strive to devote one evening a week to dawat, take part in a three-day dawat each month, a forty-day dawat each year, and go abroad on a three-month dawat once in a lifetime. In Kyrgyzstan it was rare for dawatchis to achieve and maintain perfect regularity, but the efforts to live up to this ideal had nevertheless produced an impressive forward-moving network.

The strength of the Tablighi network, similar to that of the Church of Jesus Christ, is that its missionaries are not external or separate, but constitutive of the movement as a whole. If for the Pakistani Tablighis, who first visited Kyrgyzstan, Central Asia was attractive because its Muslim population led largely irreligious lives, the same logic is replicated in the now largely indigenized movement, not least through its emphasis on doing dawat in destitute and peripheral settings (Toktogulova 2014). The focus on missionizing is omnipresent at Tablighi mosques, for example when after the Friday prayers congregants are encouraged to express the intention to go on dawat at a specified time in the near future. And when congregants talk with each other, they often start by exchanging information about their involvement in previous dawats. Such travelling experiences lend authority, and those who have taken part in longer (40-day or 3-month) dawats are likely to be chosen as amir (leader) of a new jamaat or team. 
It is during these tours, travels, or dawats that the pioneering sensation is particularly palpable. Three-day dawats typically depart from the mosque after the Friday prayers, when ideally six but up to ten men will travel to their assigned destination. They collect a small amount of money from each dawatchi, after which they travel by car or (more often) public transport to the mosque in the relevant village or town, where they usually arrive unannounced. Trying to find one's bearings in unfamiliar surroundings, needing to prepare food with minimal resources, taking care of personal hygiene in largely abandoned mosques, and sleeping on wooden planks generates a sense of improvisation, hardship and adventure. Several dawatchis compared the experience to the Soviet summer camps (lager) that they had experienced in their youth, and they stressed that the first day was often challenging. In the words of one dawatchi: 'When you arrive at the mosque you never know what to expect, you need to make do with the few available things. We buy some basic food and that is it. And yet, nowhere does food taste as good as on dawat'.

While much time on these trips is devoted to prayer and study, what stands out are the encounters with local residents and state officials. These encounters are instantly transformed into stories, and mixed with stories from previous dawats, often in an effort to generate an image of successful heroism. As Metcalf points out, 'Although the promise of paradise and reward is alluded to in the stories, it is the compelling account of heroic commitment at any cost that serve to communicate the truth and urgency of embracing the models that are held out' (1993). During the dawats in which I took part numerous stories were exchanged about encounters with suspicious officials, including one about how the previous year a group of travellers had been taken into custody, until the intervention of a local Tablighi not only allowed for their release but also resulted in a copious meal as compensation. The story was concluded by pointing out how difficult it is for police officers 
and other officials to give up their sinful lives. Nevertheless, the very presence of dawatchis would encourage such officials to reflect on the way they conduct themselves, and possibly change their lives in the future. Such stories were part of the missionary project: they pushed discursively into the frontier by outlining the sequence through which others would be brought onto the right path.

These descriptions show that Tablighi and evangelical praxis are saturated with ideas that resonate with the concept of the frontier. The missionaries saw themselves as the spearhead of light and knowledge expanding into the realm of darkness'; moreover their organizations were configured such as to arrive at 'occupying the whole area' (Kristof 1959). The topological features of the frontier emerged as a product of tensions between missionary projections and the actuality of missionary work, which intensified a sense of purpose in these religious practitioners. Indeed, for the missionaries there was a real allure in the frontier, in the idea of moving into hostile area, into a land in the grip of Satan or a terrain ravaged by decades of Soviet destructive modernization. On the frontier they felt that their presence mattered, allowing their lives to be filled with religious purpose. It was invigorating because the observed destitution, hopelessness, and immorality allowed their own truths to be confirmed. Moreover, the challenges strengthened the idea of being a revolutionary force destined to overcome difficulties and opposition. Still, these challenges can become overwhelming, at which point they may have an erosive instead of an invigorating effect. If so far expansion and dominance have been taken for granted, it is crucial to acknowledge that on the frontier nothing is stable. 


\section{Dangers of the Frontier}

Let me resort once more to Turner's 'The Frontier in American History', specifically where he speaks of the relationship between the pioneer and his surroundings:

Little by little he transforms the wilderness, but the outcome is not the old Europe

[but] a new product that is American. [That is,] the wilderness masters the colonist (Turner 1921: 4).

For Turner, this 'becoming' the wilderness is really only a first step of a coming into its own. That is, by shedding the European ballast and by absorbing qualities of his surroundings the colonist transforms himself and the wilderness into something new. Translating this to the religious frontier is not straightforward. Missionaries need to tread carefully, because any 'mutual enrichment' resulting from frontier encounters may contain the seeds of heresy (bid'ah and syncretism). So how should we see the above quotation in relation to missionary work? When is it that the integrity of the pioneer is lost? And how does this work when the encounter is not so much with the wilderness, but with people holding different ideas about the transcendental?

On the frontier the differentials between perceived superiority and inferiority are simultaneously very pronounced and at risk of collapsing or overturning. The sense of superiority was reflected in the "pioneers" discourse as well as their comportment. It was audible in the soft-spoken certainty of the dawatchis and the unwavering exclamations of pastor Kadyrjan; and it was palpable in the pioneers' fascination with heroic believers and in 
their patronizing attitude towards struggling non-believers. With each step deeper into the frontier their sense of superiority tends to grow, as it were, precisely because this reveals ever larger contrasts with the pioneer's truth or 'civilization'. And yet, as the distance from the centre increases with each step, the pioneer becomes more vulnerable, rendering missionary work inherently unstable. One reason for why this is so is because the descent into the frontier tends to have a schizophrenic quality - the sense of superiority often married to a sense of fascination with the other. ${ }^{19}$ Hence there are two main dangers associated with the frontier. The first is that the pioneer or missionary becomes merely a voice in the desert, increasingly ignored by those they encounter, which undermines the confidence on which missionary work is built - missionary work may implode as a result. The second danger is that the pioneer becomes overwhelmed by the frontier, and falls or steps over to the other side. That is, if the encounter with the other 'masters the colonist', it potentially explodes missionary work. In topological terms, when missionary work is stretched too thin, the frontier risks losing its energizing elasticity or even be folded into a different logic. These dangers are recognized by the pioneers themselves, which makes reflecting on them all the more interesting.

\section{Tablighis undermined}

The renewed visibility of Islam in public life since the late 1990s has been a contentious issue in Kyrgyzstan. Tablighis are often held up as examples of the perceived danger of increased 'fanaticism', not least because their appearance (untrimmed beards and some in white robes) as well as their practice of going door-to-door make them stand out. It is in light of this that the deputy director of the State Committee of Religious Affairs told me that 
he was grateful that the Tablighi Jamaat had a negative image among the public at large this would keep the movement in check without the state having to interfere..$^{20}$ In his words, 'when the Tablighis knock on someone's door the usual comment is "be gone" (poshel-ty)'. Dismissive attitudes were indeed common. During my participation in three dawats we made daily rounds through the villages to invite inhabitants to the afternoon prayer, but only very rarely was the invitation accepted and followed up by the invitee actually showing up at the mosque. The far more common response was for the addressee to wait until the speaker had finished, to then either briskly express disinterest or politely decline the invitation.

Such negative and evasive responses were not described as problematic by the dawatchis. According to the Tablighi code, 'the duty of the preacher ends with the communication of the message' (Masud 2000: xxi). I encountered a rather extreme example of the above when conversing with a group of dawatchis in the destitute former mining town of Ak-Tiuz. Although they already had been in the town for two days, not only was I the first person to come to their makeshift mosque in an abandoned building, I was also the first with whom they had an actual conversation. The dawatchis mentioned being struck by the level of public drunkenness in the town and what to them appeared as the sexual availability of female residents. The fact that the local population ignored them did not mean that their mission trip was a failure. As they explained to me, even their mere presence would leave behind 'footprints' and thereby prepare the ground for future missionary work. And there was more to it. Several weeks later I spoke with one of these dawatchis about his experience. He emphasized that the rampant alcoholism and severe destitution they had encountered in Ak-Tiuz had made him very aware of the emptiness and hopelessness of a life without God. The experience had spiritually invigorated him. 
It is justified to say that the method of Tabligh was particularly well suited to avert the dangers of the frontier. Their dawatchis or travellers never ventured alone into the unknown and risk being swallowed up by the frontier. All their activities - travelling to new places, inviting people to the mosque, eating and sleeping - were carried out in the company of fellow travellers. This provided an internal sounding board even when there was no external audience. Their forays into the unknown were always short, retreating to more familiar surroundings (or moving to another mosque) after three days. What is more, the home mosque and the team of travellers were presented as the very opposite of the frontier - a 'safe haven' to which the Tablighis return to find refuge from the bruising experiences of ordinary life. ${ }^{21}$ To put this in topological terms, dawat was organized as an 'immutable mobile', which purported to replicate the logic of the centre by teleporting it into the frontier (cf. Mol and Law 1994).

Ironically, it was in the familiar surroundings of the home and the everyday that more consequential dangers appeared to be hiding. As suggested, in the face of 'danger' conviction was maintained by the existence of an internal sounding board, an underlying structure. But it was exactly this that was still wanting in the everyday lives to which many Kyrgyzstani dawatchis returned after their travels (see also Nasritdinov 2012: 157). Being alone with unresponsive family members, with the demands of work in a largely secular society, and with wives who were hostile to Tablighi ideas, many struggled to keep up their motivation. It was not without reason that the following joke, with a serious undertone, was popular among my Tablighi acquaintances: 'The largest obstacle to dawat in Kyrgyzstan is Kyrgyz women'. 
This was certainly how my acquaintance Kanat experienced his predicament. He would muse about how much easier his life would have been if he had married a 'real Muslim girl'. By contrast, his actual wife Gulnaz derided what she saw as his excessive involvement with the Tablighi Jamaat. When I asked her what she thought about the movement, she replied in a dismissive and condescending tone of voice: 'Never will I join them. Their idea of a woman is to be submissive, to serve her husband, and to stay at home with the children'. It was not long after these conversations that Kanat stopped going on dawat, explaining: 'My work and marriage really started to suffer. I saw it happen with others - they lost their jobs, got divorced. So I am trying to rebalance my life now'.

The point here is that while the Tablighi model enabled the dawatchis to withstand frontier dangers, the viability of its frontier activities depended on the stability of the basis from which these activities were launched. This can be further illustrated with comments that Kyrgyzstani and Pakistani dawatchis made about each other during a joint dawat. According to the Kyrgyzstanis, the most significant difference was that the Pakistani had been born and raised in Islam. They admired the Pakistani for their certainty and stability in matters of faith. And they complained about their own difficulties of having grown up during atheist times and living in a largely secular society. By contrast, the Pakistani expressed amazement about the intensity with which Kyrgyzstanis were able to live their faith, and they repeatedly commented on their fervour and energy.

These comments suggest that for Kyrgyzstanis, the dawat experience was so intense because the men felt a release from their everyday commitments, and yet this was also why it tended to remain a 'bracketed reality'. Sustainable religious expansion depended at least partly on a strengthening of the basis from which this expansion took place. A more 'fertile' 
societal basis was certainly in the making in Kyrgyzstan. For example, Reetz points out that more and more positions of influence - including those related to policy making - are occupied by Tablighis or people favourably disposed to the movement $(2014: 135,140)$. The desire to strengthen the Tablighi network in society also translated to everyday practice. Kanat often made a point of helping out his fellow dawatchis, for example, by buying from their shops and hiring their labour for home renovation work. Among my interlocutors there was an optimistic sense that even the numerous people who had discontinued their involvement would play a positive role. As one put it, those who discontinued 'still have acquired some understanding of Islam and of our method - that will make society more open to us'. Nevertheless, for the moment the gap between life among Tablighi brothers during mission trips and life at home continued to loom large for many of the dawatchis. And this had both invigorating and destabilizing effects.

\section{Evangelicals overwhelmed}

In contrast to the six to ten people strong teams of the Tablighis, the ultimate evangelical hero is the lone missionary. Similar to mythologized portrayals of the anthropologist, the missionary is presented as facing challenges, sticking it out, and emerging victoriously. ${ }^{22}$ But as with anthropologists, there is always the danger of going native. A remarkable example of this was Richard/Risbek, an American missionary who as part of his preparation spent over a year living in a remote Kyrgyzstani town. He told me that during that year he fell in love with Kyrgyz culture and, impressed with the 'spiritual richness' of its people, became convinced that the Kyrgyz were one of the Lost Tribes of Israel. To prove this idea he embarked on a lengthy study of the Kyrgyz Manas epic, dwelling on similarities with biblical stories to 
hypothesize that the epic and the bible derived from the same source. ${ }^{23}$ Richard/Risbek was controversial in evangelical circles because his ideas demonstrated to some that 'contextualization' had turned into 'syncretism', meaning that efforts to make the biblical message locally meaningful and relevant had ended up corrupting the message, which therefore was no longer biblical. The discomfort was mutual. From Richard/Risbek's perspective, the problem was that many foreign missionaries were dogmatic in their faith, which he feared would introduce the same kind of divisions within Protestantism as exist elsewhere, and which would overshadow the spiritual message. Instead of aiming to convert the Kyrgyz to Christianity, Richard/Risbek's hope was for the Kyrgyz to reach 'the peak of their religion', and become Muslim 'followers of Jesus'.

A different kind of frontier danger was experienced by Gulbarchyn, a Kyrgyz woman in her late twenties who in 2004 had been sent by the aforementioned pastor Kadyrjan to serve as a missionary in the mining town of Kokjangak and establish a congregation of the Church of Jesus Chris. After a few months during which the prayer groups she organized were well attended, this new congregation started to dwindle. During my last encounter with Gulbarchyn we talked at length about the difficulties of living in a place whose residents were either hostile or indifferent to her presence and about how her difficulties were confounded by the partial disintegration of the congregation. She confided in me: 'I know that we will grow if we pray and work, but often I have this thought [embarrassed laugh], this strong thought that I want to move away from here... I just don't know'. She sounded despondent to me and hence I was not surprised when the following year I was informed that Gulbarchyn had left town to return to her parental home. 
One of the ironies of the frontier was that evangelical missionaries themselves increasingly became the target of Islamic mission work. Pastor Bolot, who in 2016 was leading a struggling congregation, told me: 'these dawatchis visit us all the time. They talk to my wife and my daughters, telling them that the Kyrgyz have always been Muslim and that I should come to the mosque. The result is that people become afraid. They want to follow Jesus, but they don't dare to anymore'. Bolot and his family were holding out, but he depicted the current times as one of perseverance in which God was testing their faith, and which stood in sharp contrast to the situation fifteen years previously when there had been 'a real surge' and the congregation was filled with energy.

The examples above illustrate what can happen when the frontier's invigorating qualities become overshadowed by its destabilizing effects: Richard/Risbek saw himself cut off from his evangelical home (through accusations of syncretism); Gulbarchyn lost her sense of purpose and broke off her mission to Kok-Jangak; Bolot's congregation turned inward in the face of overwhelming opposition. All of this speaks to the fragility of conviction on the frontier, but it does not mean that the invigorating qualities are unavoidably lost. At this point it is useful to return to pastor Kadyrjan, when he reflected on the size of his congregation, which at the time counted 250 tithe paying members:

If you would add up all the people who converted in our church, you would probably get to eight hundred people. It happens all the time. People join the church, and then suddenly they say that they no longer have time. And that's the end of it. What happens is that the 'open' people come to our church, but then relatives and others start to put pressure on this person, trying to convince them that they should not go 
to the church, offer money so that they won't go, and if that doesn't help, they will ostracize them. It is the usual thing; persecution is part of Christianity. We pray [for local officials] to stop hindering us. But that may not be God's way. Our faith thrives when it is being repressed.

Kadyrjan's reflections showed an awareness of both the invigorating and destabilizing forces of the frontier. And in line with the general vision of the Church of Jesus Christ, Kadyrjan's approach for dealing with the contradiction was to remain on the offensive, adopting a forward moving strategy in which constantly new battles were sought and a pioneer mentality was fostered. Numerous people fell by the wayside, but that was only to be expected because not everyone is chosen to be saved. As the church moved deeper into the frontier, the risks and failures multiplied. The frontier generated affective energies needed for missionary work, but simultaneously rendered these fragile.

This section has focused on the dark side of the frontier, showing that the dangers that accompanied its allure rendered mission work fragile. This straightforward principle, however, was confounded by the various missionary strategies to stave off these dangers. The foundational element of these strategies was the indigenization of missionary work. While foreign evangelical missionaries were active in all kinds of support roles, it was indigenous Kyrgyzstani Christians who did the actual evangelization, especially outside Kyrgyztan's capital. And while foreign Tablighi - including many Pakistani students and businessmen living in Bishkek - were instrumental in strengthening the transnational networks of faith and took part in locally organised dawats to the provinces, the teams 
(jamaats) would always consist primarily of Kyrgyzstani dawatchis. And with this principle of indigenization came the more subtle yet vital adjustments of speech and conduct that improved the efficacy of missionary efforts, allowing them to extend deeper into the frontier.

The Tablighi practice of dawat appeared to better equipped to deal with frontier dangers than the lone evangelical missionary (or even missionary family), but even so the dawatchis eventually had to return to their everyday lives in a largely secular society. Mechanisms for dealing with frontier dangers were certainly not failproof and could not always prevent the destabilization of missionary work. There were different ways of dealing with setbacks, of trying to minimize or neutralize the fallout. The Church of Jesus Christ treated backsliding and failure as collateral damage - unavoidable setbacks in the struggle between good and evil. The Tablighi perspective held that those who interrupted their active engagement had nevertheless become acquainted with a truthful life, and as such contributed to an underlying current on which new waves of expansion could thrive. But these are differences of emphasis rather than of kind. They both attest to the instable relational qualities of the frontier, seen not just as located on the margin, but as part of imperfect, and indeed fragile, projects.

\section{Frontier Dynamics}

In this article I have compared two religious missions into Central Asia, highlighting the forces that underpin the missionary drive as well as those that destabilize them. Tablighis and evangelical-Pentecostals were similarly attracted to the opportunities and challenges that the 'mission field' in Kyrgyzstan presented, but their modes of engagement differed. 
Their missions were differently organized, had different strategic visions, and related differently to Kyrgyzstani society, all of which influenced the various outcomes. But beyond the empirical interest of comparing recent forms of missionary activity in Central Asia, my aim has been to tease out several larger analytical points, and I will use this final section to reflect on them. Consecutively, these larger points refer to the relative value of conceptualizing the mission field as a frontier rather than a market, to how studying religious frontiers may illuminate other kinds of frontiers, and to an analytic understanding of the dynamics that constitute frontiers.

As discussed in the introduction, descriptions of post-Soviet religious landscapes have often relied on the notion of the market. The appeal of the market metaphor was easy to see in the case of Kyrgyzstan, where the collapse of the repressive Soviet regime was followed by a surge in religious activity. ${ }^{24}$ Not only did this trend appear to confirm the thesis of market theorists of religion that a liberal and plural religious landscape will boost religious vibrancy, ${ }^{25}$ the market concept also resonated with how my interlocutors spoke about the religious landscape in Kyrgyzstan. If state officials complained that 'religious liberalization had gone too far', missionaries talked about the 'freedom' of individuals to 'choose' the right path. Moreover, some newly active religious movements, prominently among which were the Tablighi Jamaat and evangelical-Pentecostalism, have thrived under conditions of neoliberal reform, a flourishing that cannot be wholly separated from their discursive reliance on 'choice' and 'freedom', terms that resonate with market ideology (Elisha 2015; Janson 2014). 
As long as we are aware of the fact that 'markets' are shaped by forces that escape their own logics, a market perspective can indeed be helpful to describe 'how people navigate the fragmented religious terrain of late modernity', to use the words of Ališauskiene and Schröder (2012: 4). ${ }^{26}$ However, adopting a market perspective steers the analytic gaze towards the (rational) choices and (transactional) exchanges of actors, even when the religious terrain is acknowledged not to resemble the mythical free market. ${ }^{27}$ What a market perspective tends to overlook is how the relational, affective, and epistemic factors drive religious actors and inform the encounters between them. Hence, if we want to capture how 'religious fields' (or markets) are shaped, or if we are interested in what drives religious actors, then it is important to consider alternative (or additional) perspectives. For the analysis of missionary work in newly opened or destabilized religious contexts such as in Central Asia, a frontier perspective is particularly productive.

The frontier as margin and project draws immediate attention to the interplay of positionality, relationality, and directionality in missionary work, and thereby to the affective and epistemic dimensions of missionizing. If missionizing was about 'selling truth', then the relevant sales took place within complexly constituted relationships and were dependent on the missionaries maintaining their conviction. And even if missionaries were motivated by the prospect of future gains, then these gains themselves were the product of the mystique of the frontier. All this suggests that a frontier and a market perspective can be profitably combined to highlight the complexity of religious activity, and to show how on the frontier multiple vectors produce a configuration that acquires its own dynamic. 
The religious frontier, seen as both margin and project, can be profitably compared to other kinds of frontiers. Projections of superiority and the interplay of allure and danger are certainly not unique to the religious frontier. These issues surface in writings on other frontier situations, including those pertaining to state encapsulation, extractive capitalist expansion and (neo)imperial civilizing missions. So how do the projections of superiority, the anticipations of success, and the worries about danger, as observed among Tablighi and evangelical-Pentecostal missionaries, compare to the visions and actions of other pioneers?

As mentioned above, Russian colonialism projected its Eurocentric ideas of administrative and cultural superiority onto Central Asia, with the aim to extend the empire's sovereignty, and to subject and transform the region's inhabitants (Brower and Lazzerini 1997). And to reference just one example from a different part of the world, Driessen shows in his study of the Hispano-African frontier that ideas of governmental and civilizational superiority merged in projects aimed at pacification and submission (1992: 190). However, for civilizational projects to be successful, the 'superior truth' needs to be translated to local contexts; progress can only be made through engagement with the targeted populations. The evangelical-Pentecostal and Tablighi missions offered a particularly stark view of the tensions involved, because the success of proselytizing fully depends on the message being accepted by the other, without allowing the Truth to be corrupted. So, although indigenizing the missionary effort was vital to success, the implied adjustments risked compromising the integrity of the mission.

The anticipation of gains in the face of difficulties is what drives numerous frontier activities. This is evidently true for capitalist frontiers, where the presented difficulties promise an increase of the profits to be had. A stark illustration of this logic is provided by 
Kuruüzüm's (2018) study 'Expanding war, expanding capital', which documents and analyses the scrap metal industry near the frontline with ISIS in Iraqi Kurdistan (circa 2015). It shows how entrepreneurs capitalized on existential and regulatory uncertainties. The absence of strong competition and the weakness of the regulatory framework allowed for quick enrichment, even while the war-related risks destabilized the enterprise as a whole. This same principle occurs in other 'resource frontiers', with the challenges posed by remote location, the complexity of technology, or the hostility of the socio-political environment, each of which allows the 'pioneering' entrepreneurs or companies to have an edge on their competitors. ${ }^{28}$ Frontier entrepreneurs, usually well aware of the temporary nature of their activities, 'are not seeking to impose a hegemonic territorial sovereignty' but aim to create profitable transient spaces through production and organisation (Peluso 2018: 401). The trade-offs were somewhat different on the religious frontier discussed here in that the missionaries were unlikely to produce many converts in the most hostile places, but this was (at least partly) offset by the heroism associated with taking the spiritual battle to the ultimate frontier. But here too, the evolving regulatory framework and intensifying competition suggest that we are dealing with a phenomenon that is temporally limited.

Religious missions reveal the complex interplay between assumed superiority, opportunity, and risk in particularly stark detail. This has everything to do with the position of missionaries and the nature of their work. If entrepreneurs risk bankruptcy and administrators risk defiance on the frontier, missionaries risk both severance from their religious 'home' and confrontation with those they desire to convert. The link with the religious 'home' (the church, the jamaat) was crucial to avoid accusations of syncretism or to lose sense of purpose. The sense of superiority, moreover, needed to be recognized and accepted by the other if the mission was to succeed. At the same time, it was precisely in 
relation to challenges and setbacks that a sense of religious purpose and significance was obtained.

The wildness of frontiers, Anna Tsing writes, 'is both material and imaginative' (2005: 2829). For the featured missionaries the appeal of the religious frontier was that in the 'wilderness' they could realize their purpose. There, they could imagine themselves as instruments in the hands of God, as working in a context where the Truth provided hope and salvation to shattered lives. The encounter with poverty and public drunkenness confirmed to the Tablighis that only in Islam can one find purpose. Similarly, for evangelicals the evil-infused destitution, darkness, and hostility they encountered affirmed the importance of their battle against satanic forces. The potency of the unknown intensified the sense of religious purpose and superiority, but at the same time this appeal of unrealized potential was counteracted by the danger of the unknown. When their message was ignored, when the link to the center weakened, or when opposing powers gathered force, missionaries risked losing their bearings.

Standing at the junction of these counteracting forces, the frontier emerges as a topological object that is 'organized from within itself' (Lury, Parisi, and Terranova 2012: 7) and has its own momentum. The affective energy of the frontier was produced through the projection of superiority, which meant that conviction peaked as missionaries pushed into the frontier, meanwhile becoming more unstable. As in the figure of the wave, the frontier spurs on, extends its reach, gains momentum, and releases its energy: crashing, flooding, receding. The shape, direction, and force are constituted by the affective and relational dimensions of the figuration itself, revealing the frontier as a topological object in which 
'power relationships are not so much positioned in space or extended across it, as compose the spaces of which they are part' (Allen 2011; see also Harvey 2012: 77-78). It was forwardmoving, but not in a straightforwardly territorial manner. As Rasmussen and Lund point out in their discussion of resource frontiers, instead of 'moving forward in time and space, and hence reaching a definite end, frontiers can emerge and vanish' (2018: 390). This dynamic produced a fluctuation of conviction and doubt amongst the missionaries, whose conviction peaked when confronted with manageable challenges, yet which receded in the everyday, or collapsed in the face of overwhelming resistance. As long as the link with the religious home was maintained, the image of truth and righteousness could be projected onto the horizon. But, as is the case with all projections onto a surface, the clarity of vision vanishes when critical distance is lost, thereby laying bare the frontier's central contradiction.

\section{References}

Ališauskiene, Milda, and Ingo W. Schröder. 2012. Introduction. In M. Ališauskiene and I.W. Schröder, eds., Religious Diversity in Post-Soviet Society: Ethnographies of Catholic Hegemony and the New Pluralism in Lithuania. New York: Routledge, pp. 1-16.

Allen, John. 2011. Topological Twists: Power's Shifting Geographies. Dialogues in Human Geography 1, 3: 283-98.

Anzaldúa, Gloria. 1987. Borderlands: La Frontera. San Francisco: Aunt Lute.

Balci, Bayram. 2012. The Rise of the Jama'at al Tabligh in Kyrgyzstan: The Revival of Islamic Ties between the Indian Subcontinent and Central Asia? Central Asian Survey 31, 1: 61-76.

Bassin, Mark. 1993. Turner, Solov'ev, and the 'Frontier Hypothesis': The Nationalist Signification of Open Spaces. The Journal of Modern History 65, 3: 473-511. 
Baumann, Gerd. 2004. Grammars of Identity/Alterity: A Structural Approach. In G. Baumann and A. Gingrich, eds., Grammars of Identity/Alterity: A Structural Approach. New York: Berghahn Books, pp. 18-52.

Bender, Courtney. 2015. Power of Pluralist Thinking. In W. Sullivan et al, eds., Politics of Religious Freedom. Chicago: University of Chicago Press, pp. 66-77.

Berger, Peter L. 1999. The Desecularization of the World: A Global Overview. In P. Berger, ed., The Desecularization of the World: Resurgent Religion and World Politics. Grand Rapids, Michigan: William B. Eerdmans, pp. 1-18.

Berger, Peter and Anton Zijderveld. 2009. In Praise of Doubt: How to Have Convictions Without Becoming a Fanatic. New York: Harper One.

Biehl, João, and Peter Locke. 2010. Deleuze and the Anthropology of Becoming. Current Anthropology 51, 3: 317-351.

Bielo, James S. 2011. 'How Much of This Is Promise?': God as Sincere Speaker in Evangelical Bible Reading. Anthropological Quarterly 84, 3: 631-653.

Borbieva, Noor O'Neill. 2012. Foreign Faiths and National Renewal: Christian Conversion among Kyrgyz Youth. Culture and Religion 13, 1: 41-63.

Brower, Daniel (2003) Turkestan and the Fate of the Russian Empire. London: RoutledgeCurzon.

Brower, Daniel R., and Edward J. Lazzerini, eds., 1997. Russia's Orient: Imperial Borderlands and Peoples, 1700-1917. Bloomington: Indiana University Press.

Bruce, Steve. 1999. Choice and Religion: A Critique of Rational Choice Theory. Oxford: Oxford University Press. 
Coleman, Simon, and Rosalind Hackett. 2015. Introduction: A New Field? In S. Coleman and R. Hackett, eds., The Anthropology of Global Pentecostalism and Evangelicalism. New York: New York University Press, pp. 1-37.

Crapanzano, Vincent. 2004. Imaginative Horizons: An Essay in Literary-Philosophical Anthropology. Chicago: University of Chicago Press.

Driessen, Henk. 1992. On the Spanish-Moroccan Frontier: A Study in Ritual, Power and Ethnicity. Oxford: Berg.

Elisha, Omri. 2015. Sin, Sociality, and the Unbuffered Self in US Evangelicalism. In S. Coleman and R. Hackett, eds., The Anthropology of Global Pentecostalism and Evangelicalism. New York: New York University Press, pp. 41-56.

Frank, Andre Gunder. 1992. The Centrality of Central Asia. Studies in History 8, 1: 43-97.

Froese, Paul. 2008. The Plot to Kill God: Findings from the Soviet Experiment in Secularization. Berkeley: University of California Press.

Gammeltoft, Tine. 2013. Potentiality and Human Temporality: Haunting Futures in Vietnamese Pregnancy Care. Current Anthropology 54, S7: S159-S171.

Gauthier, François, Tuomas Martikainen and Linda Woodhead (2016) Religion in Market Society. In T. Martikainen and F. Gauthier, eds., Religion in the Neoliberal age: Political Economy and Modes of Governance. New York: Routledge, pp. 1-17.

Gorder, Andrew Christian van. 2009. Post-Soviet Protestant Missions in Central Asia. East West Church \& Ministry Report 17, 2-3: 3-4.

Hann, Chris, and Mathijs Pelkmans. 2009. Realigning Religion and Power in Central Asia: Islam, Nation-State and (Post)Socialism, Europe-Asia Studies 61, 9: 1517-41. 
Harvey, Penelope. 2012. The Topological Quality of Infrastructural Relation: An Ethnographic Approach. Theory, Culture \& Society 29, 4-5: 76-92.

Hochschild, Arlie. 2011. Emotional Life on the Market Frontier. Annual Review of Sociology 37: 21-33.

Ismailbekova, Aksana, and Emil Nasritdinov. 2012.Transnational Religious Networks in Central Asia: Structure, Travel, and Culture of Kyrgyz Tablighi Jama'at. Transnational Social Review 2, 2: 177-95.

Janson, Marloes. 2014. Islam, Youth and Modernity in the Gambia: The Tablighi Jama'at. Cambridge: Cambridge University Press.

Keller, Shoshana. 2001. To Moscow, Not Mecca: The Soviet Campaign Against Islam in Central Asia, 1917-1941. Westport, CT: Praeger Publishers.

Kirmse, Stefan. 2013. Youth and Globalization in Central Asia: Everyday Life between Religion, Media, and International Donors. Frankfurt: Campus Verlag.

Khalid, Adeeb. 2007. Islam after Communism: Religion and Politics in Central Asia. Berkeley: University of California Press.

Khodarkovsky, Michael. 2002. Russia's Steppe Frontier: The making of a colonial empire, 1500-1800. Bloomington, IN: Indiana University Press.

Kopytoff, Igor. 1987. The Internal African Frontier: The Making of African Political Culture. In I. Kopytoff, ed., The African Frontier: The Reproduction of Traditional African Societies. Bloomington, IN: Indiana University Press, pp. 3-84.

Kristof, Ladis. 1959. The Nature of Frontiers and Boundaries. Annals of the Association of American Geographers 49: 269-82. 
Kuruüzüm, Umut. 2018. Expanding War, Expanding Capital: Production, Labour, and Contradictions of Contemporary Capitalism in the Kurdistan Region of Iraq. PhD Dissertation. The London School of Economics and Political Science.

Lash, Scott. 2012. Deforming the Figure: Topology and the Social Imaginary. Theory, Culture \& Society 29, 4-5: 261-287.

Lattimore, Owen. 1968. The Frontier in History. In Manners R and Kaplan D (eds) Theory in Anthropology: A Sourcebook. New York: Routledge, pp. 374-85.

Law, John. 1999. After ANT: Complexity, Naming and Topology. The Sociological Review 47, 1 suppl.: $1-14$.

Leach, Edmund R. 1954. Political Systems of Highland Burma: A Study of Kachin Social Structure. London: Athlone Press.

Liberatore, Giulia. 2015. Somali, Muslim, British: Striving in Securitized Britain. London: Bloomsbury. Limerick, Patricia Nelson. 1995. Turnerians All: The Dream of a Helpful History in an Intelligible World. The American Historical Review 100, 3: 697-716.

Louw, Maria Elisabeth. 2007. Everyday Islam in Post-Soviet Central Asia. London: Routledge.

Lury, Celia, Luciana Parisi, and Tiziana Terranova. 2012. Introduction: The Becoming Topological of Culture. Theory, Culture \& Society 29, 4-5: 3-35.

Mahmood, Saba. 2005. Politics of Piety: The Islamic Revival and the Feminist Subject. Princeton: Princeton University Press.

Masud, Muhammad Khalid. 2000. Introduction. In M. Masud, ed. Travellers in Faith: Studies of the Tablïghī Jamā'at as a Transnational Islamic Movement for Faith Renewal. Leiden: Brill, pp. xiii-|x. 
Metcalf, Barbara. 1993. Living Hadith in the Tablighi Jama'at, The Journal of Asian Studies 52, 3: 584608.

Metcalf, Barbara. 2002. Traditionalist Islamic Activism: Deoband, Tablighis, and Talibs. ISIM paper 1. Leiden University.

Mol, Annemarie, and John Law, 1994. Regions, Networks and Fluids: Anaemia and Social Topology. Social Studies of Science 24, 4: 641-71.

Moore, Jason W. 2015. Capitalism in the Web of Life: Ecology and the Accumulation of Capital. London: Verso Books.

Murzakhalilov, K. 2004. Proselytism in Kyrgyzstan. Central Asia and the Caucasus: Journal of Social and Political Studies 25, 1: 83-87.

Nasritdinov, Emil. 2012. Spiritual Nomadism and Central Asian Tablighi Travelers. Ab Imperio 2012, 2: $145-67$.

Pelkmans, Mathijs. 2006. Asymmetries on the 'Religious Market' in Kyrgyzstan. In C. Hann, ed., The Postsocialist Religious Question: Faith and Power in Central Asia and East-Central Europe. Berlin: Lit Verlag, pp. 29-46.

Pelkmans, Mathijs. 2007. 'Culture' as a Tool and an Obstacle: Missionary Encounters in Post-Soviet Kyrgyzstan. Journal of the Royal Anthropological Institute 13, 4: 881-899.

Pelkmans, Mathijs. 2009. The Transparency of Christian proselytizing in Kyrgyzstan. Anthropological Quarterly 82, 2: 423-46.

Pelkmans, Mathijs. 2014. Paradoxes of Religious Freedom and Repression in (Post-)Soviet Contexts. Journal of Law and Religion 29, 3: 436-446.

Pelkmans, Mathijs. 2017. Fragile Conviction: Changing Ideological Landscapes in Urban Kyrgyzstan. Ithaca: Cornell University Press. 
Peluso, Nancy Lee. 2018. Entangled Territories in Small-Scale Gold Mining Frontiers: Labor Practices, Property, and Secrets in Indonesian Gold Country. World Development 101: 400-416.

Radford, David. 2015. Religious Identity and Social Change: Explaining Christian Conversion in a Muslim World. London: Routledge.

Rasmussen, Mattias Borg, and Christian Lund. 2018. Reconfiguring Frontier Spaces: The Territorialization of Resource Control. World Development 101: 388-399.

Reetz, Dietrich. 2017. Mediating Mobile Traditions: The Tablighi Jama'at and the International Islamic University between Pakistan and Central Asia (Kyrgyzstan, Tajikistan). The Journal of Transcultural Studies 8, 1: 123-168.

Rotar, Igor. 2007. Pakistani Islamic Missionary Group Establishes a Strong Presence in Central Asia. July 23. Eurasianet.org. http://www.eurasianet.org/departments/insight/articles/eav072307a.shtml.

Roy, Olivier. 2006. Globalized Islam: The Search for a New Ummah. New York: Columbia University Press.

Scott, James C. 2009. The Art of Not Being Governed: An Anarchist History of Upland Southeast Asia. New Haven: Yale University Press.

Stark, Rodney and Roger Finke. 2000. Acts of Faith - Explaining the Human Side of Religion. Berkeley: University of California Press

Toktogulova, Mukaram. 2014. The Localisation of the Transnational Tablighi Jama'at in Kyrgyzstan: Structures, Concepts, Practices and Metaphors. Crossroads Asia Working Paper Series, No. 17. 
Tozy, Mohamed. 2000. Sequences of a Quest: Tablīghī Jamā'at in Morocco. In M. Masud, ed., Travellers in Faith: Studies of the Tablïghī Jamā'at as a Transnational Islamic Movement for Faith Renewal. Leiden: Brill, pp. 161-73.

Tsing, Anna Lowenhaupt. 2003. Natural Resources and Capitalist Frontiers. Economic and Political Weekly 38, 48: 5100-5106.

Tsing, Anna. 2005. Friction: An Ethnography of Global Connection. Princeton, NJ: Princeton University Press.

Turner, Frederick Jackson. 1921. The Frontier in American History. New York: Henry Holt.

Veer, Peter van der. 2012. Market and Money: A Critique of Rational Choice Theory. Social Compass 59, 2: 183-192.

Vladimir, Archbishop of the Orthodox Diocese of Bishkek and All Central Asia. 2000. Christianity and Islam in Central Asia. In R. Sagdeev and S. Eisenhower, eds., Islam and Central Asia: An Enduring Legacy or an Evolving Threat? Washington, DC: Center for Political and Strategic Studies.

Vladimir, Mitropolit Bishkekskii i Sredneaziatskii. 2002. Zemlia potomkov patriarkha tiurka: dukhovnoe nasledie kirgizii i khristianskie aspekty etogo naslediia. Moscow: Izdatel'stvo Moskovskoi Patriarkhii.

Winter, Ralph D. 2005. What Are Mission Frontiers? International Journal of Frontier Missions 22, 4: 155-58.

\section{Endnotes}


${ }^{1}$ This article is based on materials collected during twenty months of ethnographic fieldwork between 2003 and 2015.

${ }^{2}$ I use the adjective 'Kyrgyzstani' as a civic marker (i.e. relating to the country Kyrgyzstan) and 'Kyrgyz' as an ethno-national marker (i.e. relating to the Kyrgyz nation).

${ }^{3}$ Archbishop Vladimir, for example, emphasized that Orthodox Christianity is not a proselytizing faith and has few native Central Asian adherents (Vladimir 2000: 95). In 1995 Orthodox Christian and Sunni Muslim representatives jointly declared their 'interest in strengthening the spirit of Islam amongst the Muslim nations and the Orthodox Christian spirit amongst the Slavic populations, in recognition that those creeds are a legacy of our forefathers' (cited in Vladimir 2002: 289).

${ }^{4}$ The quote is from Mark Palmer, coordinator of the U.S. based mission organization Campus Crusade for Christ in Kyrgyzstan between 1992 and 2004 (quoted in Pelkmans 2006: 29).

${ }^{5}$ By the same token one could say that I didn't consider these men equal conversation partners either, but used them to advance my research interests, and moreover objectified them through my writing. This goes to show that issues of ideological dominance are rarely straightforward and subject to logics of inversion and subversion, as is certainly true on the frontier, as we will see below.

${ }^{6}$ The Church's name in Russian is Tserkov' Isusa Khrista. The Church of Jesus Christ should not be confused with the Mormon Church of Jesus Christ of Latter Day Saints, with which it has no connection whatsoever.

${ }^{7}$ For detailed discussions of the Tablighi Jamaat in Kyrgyzstan, see Balci (2012), Nasritdinov (2012), Pelkmans (2017: 102-123), Reetz (2017), Toktogulova (2014). For detailed 
discussions of evangelical Christianity in Kyrgyzstan see Borbieva (2012), Pelkmans (2006; 2007; 2017: 124-47); Radford (2015),

${ }^{8}$ As Berger and Zijderveld (2009: 7-12) point out, 'pluralism' highlights the erosion of traditional structures and the appearance of new religious movements.

${ }^{9}$ Let me reemphasize that I do not wish to discard the market perspective. Rather, I argue that its focus on choice, exchange, and competition creates the tendency to leave other aspects of the social field unseen. The perspectival shift applied in this article-adopting the prism of the frontier - foregrounds some such other aspects, allowing us to examine how relational, affective, and epistemic factors influence the shape and dynamics of the mission field.

${ }^{10}$ Using Turner's own words, Limerick shows that instead of being self-reliant, pioneers found themselves in a state of dependence 'on the strong arm of national power' (1995: 700). Other critics (e.g. Bassin 1993) have pointed out that the availability of land resulted not so much in innovation as in wastefulness.

${ }^{11}$ Within four months after the disintegration of the USSR in 1991 Kyrgyzstan had adopted a religion law that lifted virtually all restrictions on religious activity. In contrast to what happened in neighbouring countries this law was actually implemented, and until around 2008 state interference in religious affairs was minimal. During this period, however, political actors increasingly opined that religious liberalization that 'had gone too far' (Murzakhalilov 2004, pp. 86-87). This set the stage for more restrictive legislation, with the first such law (which prohibited proselytization) adopted in 2008. Due to ongoing political turmoil and limited state capacity the implementation of this law has been slow and uneven (see Pelkmans 2014 for details). 
12 The concept of the 'network' that Mol and Law (1994) advance relies on Latour's idea of the 'immutable mobile' - that which (ostensibly) stays the same when it moves (or is replicated) across space and time.

${ }^{13}$ In the evangelical context, the term 'frontier' features in names such as the Frontier Missions journal and the International Journal of Frontier Missions, and in mission organizations such as Frontiers (http://frontiers.org/) which targets the Muslim world. ${ }^{14}$ In the mid-1990s the U.S. based International Journal of Frontier Missions devoted at least six articles to mission work in Central Asia, focusing on unreached people in Kazakhstan, Tajikistan, Uzbekistan, Mongolia Turkmenistan, and Kyrgyzstan (vol.10, issue 1, 2; vol.11, issue 2 and 3; vol.12, issue 1; vol.15 issue 1).

${ }^{15}$ The book Kazhdyi Khristianin - Missioner (Every Christian is a Missionary) originally appeared in English under the title The World Christian Starter Kit, written by Glenn Myers (1986).

${ }^{16}$ Similarly, the church's weekly newspaper Tvoi Put': Khristanskaia Gazeta always contained several exemplary stories of how congregants had received God's grace. ${ }^{17}$ I have described this event in more detail elsewhere (Pelkmans 2007: 881-883).

${ }^{18}$ Metcalf mentions that Tablighis in South Asia refer to their activities as jihad, understood as effort or struggle (2002: 11). My Tablighi acquaintances in Kyrgyzstan never mentioned jihad but instead spoke of dawat to talk about these efforts.

${ }^{19}$ That is to say, Baumann's (2004) reminder that the Orientalizing gaze is not only condescending of primitiveness but also desiring of lost purity similarly applies to evangelical and Tablighi missionaries. 
${ }^{20}$ The deputy director made this comment in 2009, after I asked him about a new religion law that explicitly forbade proselytization, but which was not enforced in the case of the Tablighi Jamaat. For a discussion of the evolving legal situation, see Pelkmans (2014). ${ }^{21}$ Invoking to the movement's 'dry dock parable', Mohamed Tozy compares worldly life to a ship in trouble in tumultuous sea which can only be repaired in the 'dry-dock' of the jamaat or the mosque (Tozy 2000: 166).

${ }^{22}$ A sample of this evangelical glorification of the lone missionary can be found in: Vance Christie (2004) Into all the World: Four Stories of Pioneer Missionaries. Barbour Publishing. ${ }^{23}$ Richard/Risbek wrote several books about this, the first of which appeared in English and in Kyrgyz as Ak Kalpak in 2003. In later years he wrote a more elaborate account, which was also self-published, and appeared as: Risbek (Richard Hewitt). 2012. Manas Lost \& Found: A Bridge Linking Kyrgyzstan's Epic to Ancient Oracles.

${ }^{24}$ Peter van der Veer has similarly argued for China that a main reason for the popularity of a market perspective in studies of religion is its history of religious repression (2012: 184).

${ }^{25}$ This is a central argument in market theories of religion, not least in the foundational work of Rodney Stark and Roger Finke (e.g. 2000). It is perhaps ironic that although their student Paul Froese agrees that the end of Soviet Union saw a clear increase of religious movements (the supply side), he concludes for the demand side that "pluralism appears to have no effect on religious growth" across the region (2008: 145, 154).

${ }^{26}$ For the case of Kyrgyzstan, Stefan Kirmse's Youth and Globalization in Central Asia (2013) offers a particularly useful and nuanced example of such an approach. The work of Gauthier, Martikainen, and Woodhead (2013) is a powerful example of a market approach that is attentive to its moral construction. 
${ }^{27}$ These problems have often been discussed. To offer just a few examples: Van der Veer (2012) points out that the focus on choice does not only reflect an individualist bias, but tends to reduce human behaviour to maximization of gains; Steve Bruce argues that a focus on transaction overlooks what he considers to be the essence of religion - its emotive, epistemic and relational qualities (1999). On the point of transactional exchange (and looking beyond the field of religion), it is useful to quote Hochschild's 'market frontiers' (2011), a term she uses to think about how the logic of exchange may give way to other logics such as those of morality and emotion. In her study of surrogacy she shows how the boundary between the logics of exchange, morality, and emotion is being pushed back and forth, meaning that the 'market' is a fluctuating and contingent process that needs to be explained and should not be assumed to describe a pre-existing 'field'.

${ }^{28}$ The dynamic is more than a surface feature - it is central to political, economic, and religious projects of expansion and intensification. Jason W. Moore, in Capitalism in the Web of Life, goes as far to suggest that capitalism 'is a frontier process: endless accumulation and endless geographical appropriation are jointed at the hip' (2015: 107). 